\title{
Hypolipidemic activity of Moringa oleifera Lam., Moringaceae, on high fat diet induced hyperlipidemia in albino rats
}

\author{
Pankaj G. Jain, "Savita D. Patil, Nitin G. Haswani, Manoj V. Girase, Sanjay J. Surana
}

\author{
R.C. Patel Institute of Pharmaceutical Education and Research, Near Karwand Naka, Shirpur-425 405, Dist- Dhule, \\ Maharashtra, India.
}

\begin{abstract}
RESUMO: "Atividade hipolipidemica de Moringa oleifera Lam., Moringaceae, na hiperlipidemia induzida por dieta rica em gordura em ratos albinos." As folhas de Moringa oleifera Lam., Moringaceae, são usados na medicina natural da Índia como um agente hipolipemiante em pacientes obesos. Ratos albinos Wistar foram alimentados com extrato metanólico de M. oleifera $(150,300$ e $600 \mathrm{mg} / \mathrm{kg}$, p.o.) e sinvastatina (4 mg/kg, p.o.), juntamente com dieta hiperlipídica por 30 dias. Moringa oleifera e sinvastatina reduziram o colesterol, triacilglicerídeoss, VLDL, LDL e índice aterogênico, mas não aumentaram o HDL em comparação com o grupo controle, com dieta rica em colesterol. O mecanismo de ação do extrato metanólico de Moringa oleifera foi também investigado estimando atividade de HMG CO-A redutase. Moringa oleifera aumentou a excreção fecal de colesterol. Assim, o estudo demonstra que a $M$. oleifera parece ter efeito hipolipemiante.
\end{abstract}

Unitermos: Moringa oleifera, HMG Co-A reductase, hypolipidemic effect, lipid profile.

\begin{abstract}
The leaves of Moringa oleifera Lam., Moringaceae, are used by the Indians in their herbal medicine as a hypolipidemic agent in obese patients. Albino Wistar rats were fed with methanolic extract of $M$. oleifera $(150,300$ and $600 \mathrm{mg} / \mathrm{kg}$, p.o.) and simvastatin $(4 \mathrm{mg} /$ $\mathrm{kg}$, p.o.) along with hyperlipidemic diet for 30 days. Moringa oleifera and simvastatin were found to lower the serum cholesterol, triacylglyceride, VLDL, LDL, and atherogenic index, but were found to increase the HDL as compared to the corresponding high fed cholesterol diet group (control). The Moringa oleifera methanolic extract was also investigated for its mechanism of action by estimating HMG CO-A reductase activity. Moringa oleifera was found to increase the excretion of fecal cholesterol. Thus, the study demonstrates that $M$. oleifera possesses a hypolipidemic effect.
\end{abstract}

Keywords: Moringa oleifera, HMG Co-A reductase, hypolipidemic effect, lipid profile.

\section{INTRODUCTION}

Cardiovascular disease is leading cause of death in India as well as in western countries. Hyperlipidemia is a collective term used to describe human conditions when a plasma level of one or more classes of lipids, namely cholesterol, triacylglycerides, phospholipids and fatty acids increases above normal levels. Hyperlipidemia is one of the major causes of the development of cardiovascular disorders (Raida et al., 2008).

Various parts of the Moringa oleifera Lam., Moringaceae, tree have been studied for several pharmacological actions. The aqueous extract of leaves of M. oleifera was reported for the wound healing (Rathi et al., 2006) and antiurolithiasis activity (Karadi et al., 2006). The methanolic crude extract of M. oleifera shows antibacterial activity (Nantachit, 2006). The bark extract has been shown to possess antifungal and antitubercular activity (Bhatnagar et al., 1961). The ethanolic and aqueous extract of pods was found to be hypotensive (Faizi et al., 1998).

In many cultures of the world, herbal remedies are increasingly being employed in an attempt to achieve the same purpose. In India, for instance, the leaves of Moringa oleifera Lam. is claimed to possess cholesterol-reducing effect and is used to treat patients with heart disease and obesity. For this reason it was decided to resolve this claim by investigating the effects of the methanolic extract of leaves of Moringa oleifera Lam. (English: Horseradish plant or drumstick tree) on the lipid profile of the Wistar rat using experimental hyperlipidaemic animal model. 


\section{MATERIAL AND METHODS}

\section{Plant material}

The plant material was collected from local area of Shirpur in Dhule district, Maharastra, India. At the time of collection whole plant including leaves, pods and flower were collected and authentication was made by Dr. D.A. Patil, Professor, HOD, Department of Botany S.S.V.P.S's College of Science; Dhule (Maharashtra). The voucher specimen (number 190647) was deposited for future reference.

\section{Extraction}

Leaves of the plant were removed and dried under shade in a room. After ten days of drying leaves were pulverized and sieved with a 40 \# sieve. Moringa oleifera powder was extracted in methanol by using Soxhlet apparatus. The extract was dried in vacuum evaporator below $40{ }^{\circ} \mathrm{C}$ and sterilized through Whatmann filter no. 42 and reconstituted in saline.

\section{Phytochemical investigation of extract}

Different chemical constituents present in methanolic extract were subjected to the tests by Kokate (1994) and Trease \& Evans (1997).

\section{HPTLC study}

$\beta$-sitosterol important chemical constituent of extract was detected using HPTLC fingerprint obtained using a Camag Linomat applicator and detector. The plates were observed under UV light after spraying with vanillin-con $\mathrm{HCl}$ reagent.

\section{Animals}

Healthy male albino Wistar rats of 180-200 g body weight were used in this study. The rats were housed in polypropylene cages under standard conditions $(12 \mathrm{~h}$ light and dark cycles, at $25 \pm 30{ }^{\circ} \mathrm{C}$ and $35-60 \%$ humidity). Standard palletized feed (Amrut Pellets for rat, Pune, India) and tap water were provided ad libitum. Study was approved by Institutional Animal Ethical Committee CPCSEA, India (Registration No.651/02/C/CPCSEA).

\section{Chemicals}

Cholesterol, cholic acid (Loba-chemie Ltd), triacylglyceride, HDL kits (RFCL Diagnostic Pvt. Ltd), simvastatin (Aitemis biotech Ltd.), methanol were used in this study.

\section{Preparation of the hyperlipidemic diet}

The high fat diet was prepared by mixing calculated amounts of $2 \%$ cholesterol, $1 \%$ cholic acid and $1 \mathrm{~mL}$ coconut oil. The Parachute coconut oil was chosen because of its high saturated fat content which aggravates the atherogenic profile in the rats (Hassarajani et al., 2007).

\section{Cholesterol fed diet hyperlipidemia}

Animals were divided into six groups $(\mathrm{n}=6)$. Normal group (Group I) received normal diet ad libitum. Control group (Group II) received high fat diet (HFD). After fifteen days groups IV, V, VI received high fat diet along with the plant methanolic extract in the dose of 150,300 and $600 \mathrm{mg} / \mathrm{kg}$, p.o., for thirty days. Group III received simvastatin the standard drug in the dose of $4 \mathrm{mg} / \mathrm{kg}$ p.o. after fifteen days along with high fat diet. After thirty days blood was withdrawn by cardiac puncture, allowed to clot for $45 \mathrm{~min}$ and serum was separated by centrifugation and lipid profile was done by using commercially available kits, with the help of ELISA reader (Biotech USA) (Hassarajani et al., 2007).

\section{Fecal cholesterol excretion}

Fecal matter was collected during the last three days of treatment period. The dried and powered fecal matter was extracted with $\mathrm{CHCl}_{3}: \mathrm{MeOH}(2: 1)$. The resultant extract was then analyzed for cholesterol contents in a manner similar to that the serum. The cholesterol excreted in the fecal matter $(\mathrm{mg} / \mathrm{g})$ was calculated.

\section{HMG-CoA reductase activity}

For the estimation of HMG-CoA reductase activity five group of rats were used and each group containing six animals (Venugopala \& Ramakrishnan, 1975).

Group I: Vehicle control $(0.5 \mathrm{~mL}$ carboxy methyl cellulose solution) for seven days; Group II: Test drug treated $(150 \mathrm{mg} / \mathrm{kg})$ for seven days; Group III: Test drug treated $(300 \mathrm{mg} / \mathrm{kg})$ for seven days; Group IV: Test drug treated $(600 \mathrm{mg} / \mathrm{kg})$ for seven days; Group V: Simvastatin treated $(4 \mathrm{mg} / \mathrm{kg})$ for seven days.

The liver tissue was removed as quickly as possible and a $10 \% \mathrm{w} / \mathrm{v}$ homogenate was prepared in saline arsenate solution. The homogenate was deproteinized using an equal volume of dilute perchloric acid and allow to stand for $5 \mathrm{~min}$, followed by centrifugation. To $1 \mathrm{~mL}$ of the filtrate, $0.5 \mathrm{~mL}$ of freshly prepared (alkaline hydroxylamine reagent in the case of HMG-CoA) was added. It was mixed and $1.5 \mathrm{~mL}$ of ferric chloride reagent was added after $5 \mathrm{~min}$. The absorbance was read after 10 min at $540 \mathrm{~nm}$ vs a similarly treated saline arsenate blank. 
The ratio of HMG-CoA/mevalonate was calculated.

\section{Biochemical assays for lipids}

Cholesterol, HDL and triacylglyceride levels were estimated from serum by CHOD-PAP method and GPO-PAP method (Devi \& Sharma, 2004), respectively. LDL and VLDL-cholesterol were calculated following the method by Johnson et al. (1997). While the atherogenic index was calculated by using the method described by Muruganandan et al. (2005).

\section{Statistical analysis}

Results are expressed as mean \pm SEM (standard error mean) and subjected to one-way analysis of variance (ANOVA) followed by Dunnett's test and values with $p<0.05$ were considered to be statistically different.

\section{RESULTS AND DISCUSSION}

The percentage yield of the methanolic extract was found to be $47.2 \% \mathrm{w} / \mathrm{w}$. Phytochemical investigation was performed and the following compounds were identified: glycoside, steroids flavonoids and alkaloids. A $36.57 \%$ of $\beta$-sitosterol was present in crude extract of Moringa oleifera quantified through HPTLC results (Figure1).

There was significant increase in the levels of serum cholesterol, triacylglyceride and LDL-c and a decrease in level of HDL-c in the high fat diet fed animals when compared to normal fed rats. Elevated level of blood cholesterol especially LDL-c is a known major risk factor for CHD whereas HDL-c is cardio protective. Treatment with methanolic extract, at three different doses significantly decreased the levels of total cholesterol and LDL-c as compare to the controls (Tenpe et al., 2007) (Table 1).

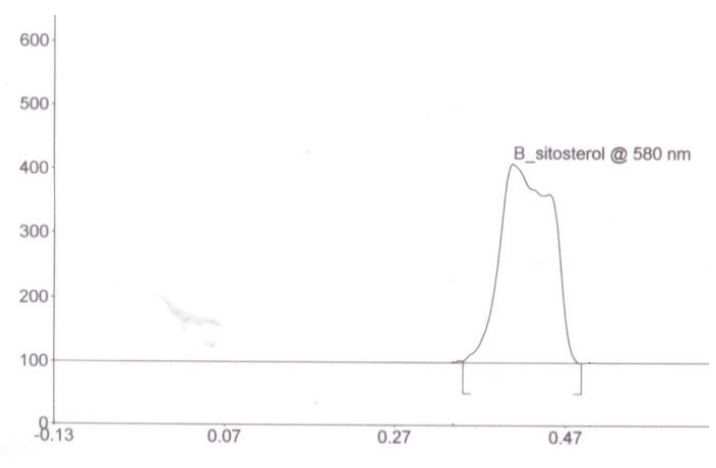

A
Atherogenic index indicates the deposition of foam cells or plaque or fatty infiltration or lipids in heart, coronaries, aorta, liver and kidneys. The higher the atherogenic index, the higher is the risk of the above organs for oxidative damage (Mehta et al., 2003). Atherogenic index was significantly reduced in the $M$. oleifera treated groups.

HFD causes the oxidative stress which finally increases production of reactive oxygen species. An increasing scientific literature provides ample direct or indirect evidence that overproduction of ROS can induce cellular damage via oxidation of critical cellular components such as membrane lipids, proteins, and DNA.

Since the result of the study indicated that the methanolic extract of M. oleifera has beneficial effect on lipid profile we have investigated its mechanism of action. Cholesterol homeostasis is maintained by the two processes viz. cholesterol biosynthesis in which HMG-Co-A reductase catalyzes rate limiting process and cholesterol absorption of both dietary cholesterol and cholesterol cleared from the liver through biliary secretion (Hassarajani et al., 2007).

The HMG-Co-A/mevalonate ratio has an inverse relationship to the activity HMG-Co-A reductase. The result of the study indicated that the activity of the enzyme is significantly depressed by the methanolic extract of M. oleifera as is evidenced by the increase in the ratio. There was significant increase in the ratio of HMG-CoA/mevalonate in the test drug at the dose of 600 $\mathrm{mg} / \mathrm{kg}(p<0.05)$ and in the standard drug at the dose of 4 $\mathrm{mg} / \mathrm{kg}(p<0.01)$ as compare to the control group (Table 2$)$. Methanolic extract at doses of $300 \mathrm{mg} / \mathrm{kg}(p<0.05), 600$ $\mathrm{mg} / \mathrm{kg}(p<0.01)$ and standard drug simvastatin $(p<0.01)$ shows significant increase in cholesterol excretion when compared with HFD control group (Figure 2).

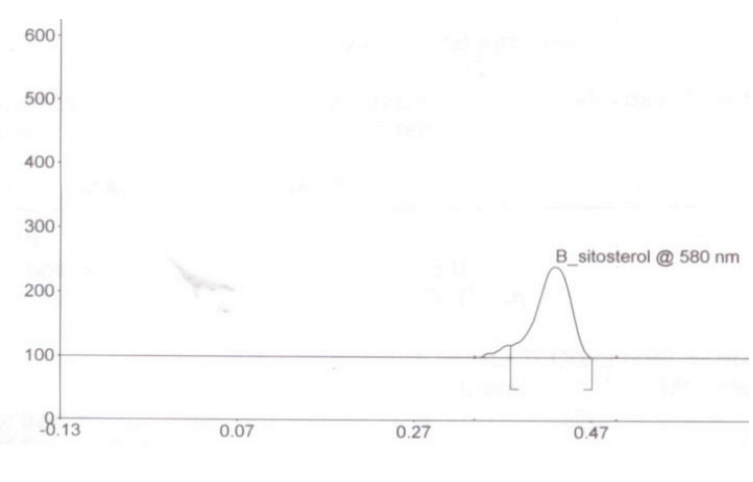

B

Figure 1. HPTLC peak of standard $\beta$-sitosterol (A) and of Moringa oleifera Lam., Moringaceae (B) at $580 \mathrm{~nm}$. 
Table 1. Effect of methanolic extract of Moringa oleifera Lam. on lipid profile in cholesterol fed hyperlipidemic rats

\begin{tabular}{lcccccc}
\hline \multicolumn{1}{c}{ Groups } & $\begin{array}{c}\text { Cholesterol } \\
(\mathrm{mg} / \mathrm{dl})\end{array}$ & $\begin{array}{c}\text { Triacylglyceride } \\
(\mathrm{mg} / \mathrm{dl})\end{array}$ & $\begin{array}{c}\text { VLDL } \\
(\mathrm{mg} / \mathrm{dl})\end{array}$ & $\begin{array}{c}\text { LDL } \\
(\mathrm{mg} / \mathrm{dl})\end{array}$ & $\begin{array}{c}\text { HDL } \\
(\mathrm{mg} / \mathrm{dl})\end{array}$ & $\begin{array}{c}\text { Atherogenic } \\
\text { index }\end{array}$ \\
\hline Normal\# & $84.40 \pm 2.45$ & $122.2 \pm 6.78$ & $24.44 \pm 1.35$ & $15.16 \pm 1.99$ & $45.20 \pm 1.50$ & $0.89 \pm 0.09$ \\
Control (HFD) & $196.8 \pm 7.01$ & $200.2 \pm 5.31$ & $40.04 \pm 1.06$ & $116.2 \pm 7.45$ & $40.60 \pm 1.29$ & $3.87 \pm 0.25$ \\
Simvastatin $4 \mathrm{mg} / \mathrm{kg}$ & $99.20 \pm 2.74^{* *}$ & $86.60 \pm 3.54^{* *}$ & $17.32 \pm 0.71^{* *}$ & $22.68 \pm 4.84^{* *}$ & $59.20 \pm 2.45^{* *}$ & $0.69 \pm 0.10^{* *}$ \\
MeOH Extract $150 \mathrm{mg} / \mathrm{kg}$ & $183 \pm 5.13$ & $182 \pm 2.89^{*}$ & $36.40 \pm 0.58^{*}$ & $105.6 \pm 6.21$ & $41 \pm 1.82$ & $3.51 \pm 0.30$ \\
MeOH Extract $300 \mathrm{mg} / \mathrm{kg}$ & $142.6 \pm 2.92^{* *}$ & $169.2 \pm 3.96^{* *}$ & $33.84 \pm 0.80^{* *}$ & $61.36 \pm 3.40^{* *}$ & $47.40 \pm 1.21^{*}$ & $2.01 \pm 0.08^{* *}$ \\
MeOH Extract $600 \mathrm{mg} / \mathrm{kg}$ & $121.2 \pm 3.88^{* *}$ & $157.4 \pm 4.55^{* *}$ & $31.48 \pm 0.91^{* *}$ & $38.72 \pm 4.06^{* *}$ & $51 \pm 1.52^{* *}$ & $1.38 \pm 0.09^{* *}$ \\
\hline
\end{tabular}

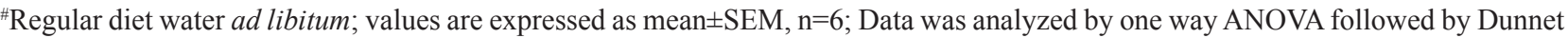
test; ${ }^{*} p<0.01$, very significant; ${ }^{*} p<0.05$, significant.

Table 2. Effect of methanolic extract of Moringa oleifera on HMG-CoA reductase activity.

\begin{tabular}{lc}
\hline Group & $\begin{array}{c}\text { Absorbance ratio } \\
(\text { mean } \pm \text { SEM })\end{array}$ \\
\hline Control & $1.489 \pm 0.1512$ \\
Methanolic extract $150 \mathrm{mg} / \mathrm{kg}$ & $1.513 \pm 0.139$ \\
Methanolic extract $300 \mathrm{mg} / \mathrm{kg}$ & $1.718 \pm 0.217$ \\
Methanolic extract $600 \mathrm{mg} / \mathrm{kg}$ & $2.126 \pm 0.233^{*}$ \\
Simvastatin $4 \mathrm{mg} / \mathrm{kg}$ & $3.133 \pm 0.223^{* *}$ \\
\hline
\end{tabular}

Values are expressed as mean \pm SEM, $n=6$; data was analyzed by one way ANOVA followed by Dunnet test; ${ }^{* *} p<0.01$, very significant; ${ }^{*} p<0.05$, significant.

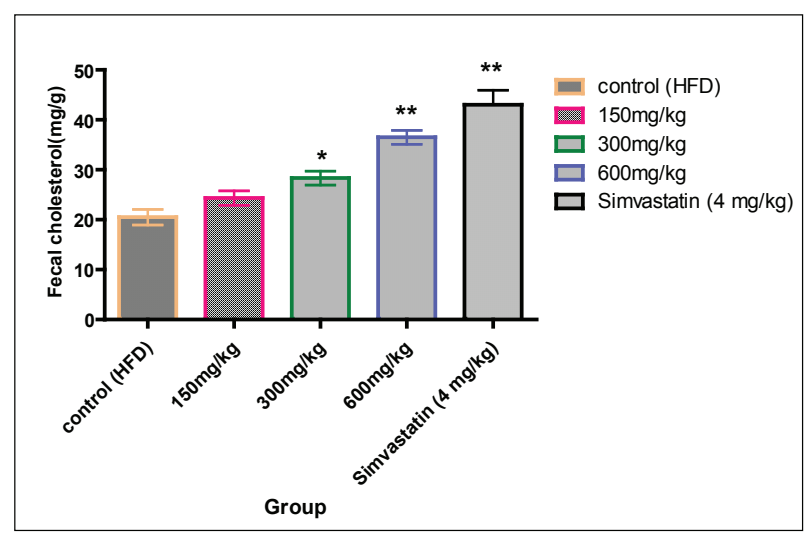

Figure 2. Effect of methanolic extract $(150,300,600 \mathrm{mg} / \mathrm{kg})$ and simvastatin drug $4 \mathrm{mg} / \mathrm{kg}$ on the excretion of cholesterol in rats each value represents the mean \pm of six rats, ${ }^{*} p<0.05$, $* * p<0.01$ vs. control.

Plant sterols inhibit the absorption of dietary cholesterol, but the resulting decrease in serum cholesterol has been slight (Saluja et al., 1978). Although M. oleifera has been shown to contain $\beta$-sitosterol in HPTLC, $\beta$-sitosterol is a plant sterol with a structure similar to that of cholesterol, except for the substitution of an ethyl group at $\mathrm{C} 24$ of its side chain. The cholesterol lowering effect may be due to this inhibition in reabsorption of cholesterol from endogenous sources in association with a simultaneous increase in its excretion into feces in the form of neutral steroids. The increased fecal excretion of cholesterol observed with M. oleifera treated group as compared to the HFD control group.

Conclusively, the observed cholesterol reducing action of the methanolic extract of Moringa oleifera Lam. indicates the hypolipidemic activity.

\section{REFERENCES}

Bhatnagar SS, Santapau H, Desai JDH, Yellore S, Rao TNS 1961. Biological activity of Indian medicinal plants. Part 1. Antibacterial, antitubercular and antifungal action. Indian J Med Res 49: 799-805.

Devi RK, Sharma DK 2004. Hypolipidemic effect of different extracts of Clerodendron colebrookianum Walp in normal and high-fat diet fed rats. J Ethnopharmacol 90: 63-68.

Faizi S, Siddiqui BS, Saleem R, Aftab K, Shaheen F, Gilani AH 1998. Hypotensive constituents from the pods of Moringa oleifera. Planta Med 64: 225-228.

Hassarajani S, Souza TD, Mengi SA, Chattopadhayay 2007. Efficacy study of the bioactive fraction (F-3) of Acorus calamus in hyperlipidemia. Indian J Pharmacol 39: 196-200.

Johnson R, McNutt P, MacMahon S, Robson R 1997. Use of the friedewald formula to estimate LDL-cholesterol in patients with chronic renal failure on dialysis. Clin Chem 43: 2183-2184.

Karadi RV, Gadge NB, Alagawadi KR, Savadi RV 2006. Effect of Moringa oleifera root wood on ethylene glycol induced urolithiasis in rats. J Ethnopharmacol 105: 306-311.

Kokate CK 1994. Practical Pharmacognosy. Vallabh Prakashan, New Delhi, 107-111.

Mehta LK, Balaraman R, Amin AH, Bafna PA, Gulati OD 2003. Effect of fruits of Moringa oleifera on the lipid profile of normal and hypercholesterolaemic rabbits. $J$ Ethnopharmacol 86: 191-195.

Muruganandan S, Srinivasan K, Gupta S, Gupta PK, Lal J 2005. Effect of mangiferin on hyperglycemia and atherogenicity in streptozotocin diabetic rats. $J$ 
Ethnopharmacol 97: 497-501.

Nantachit K 2006. Antibacterial activity of the capsule of Moringa oleifera. CMU J Nat Sci 5: 365-368.

Raida K, Nizar A, Barakat S 2008. The Effect of Crataegus aronica aqueous extract in rabbits fed with high cholesterol diet. Eur J Sci Res 22: 352-360.

Rathi BS, Bodhankar SL, Baheti AM 2006. Evaluation of aqueous extract of Moringa oleifera for wound healing in albino rats. Indian J Exp Biol 44: 898-901.

Saluja, MP, Kapil, RS, Popli, SP 1978. Studies in medicinal plants: part VI. Chemical constituents of Moringa oleifera Lam. (hybrid variety) and isolation of 4-hydroxymellein. Indian J Chem B 16B: 1044-1045.

Tenpe CR, Thakre AB, Upaganlawar AB, Yeole PG 2006. Hypolipidemic and weight controlling activity of Terminalia catappa in rats on sucrose high fat diet. Indian Drugs 44: 16-20.

Trease GE, Evans MC 1983. Textbook of Pharmacognosy. $12^{\text {th }}$ edition, Balliere Tindall, pp: 343-383.

Venugopala A, Ramakrishnan S 1975. Indirect assessment hydroxymethylglutaryl-CoA reductase (NADPH) activity in liver tissue. Clin Chem 21: 1523-1525. 